\title{
Genetic basis of the probiotic properties of Lactobacillus
}

\author{
Nikita Korostylev1,, ${ }^{1,}$ Evgenia Prazdnova1, Maria Mazanko1, Besarion Meskhi², \\ Dmitry Rudoy ${ }^{2}$, Alexey Ermakov ${ }^{2}$, Anastasiya Olshevskaya ${ }^{2}$, Andrey Chistyakov $^{2}$, and \\ Viktor Zharov ${ }^{2}$ \\ ${ }^{1}$ Southern Federal University, 194/1, pr. Stahky, 344090, Rostov-on-Don, Russia \\ ${ }^{2}$ Don State Technical University, 1, sq. Gagarina, 344003, Rostov-on-Don, Russia
}

\begin{abstract}
The aim of the study is to search and systematize genes associated with the probiotic properties of strains of the genus Lactobacillus, which are symbionts of the gastrointestinal tract of animals. The following purpose were pursued in the study: to establish the molecular features of the probiotic properties of strains of the genus Lactobacillus; to find the genes associated with probiotic properties of Lactobacillus strains; to systematize the genes found according to the molecular characteristics of their products; to characterize these genes, evaluate perspectives of searching for new and using already found ones. Various genomic and proteomic databases were used to search for information on the genetics of probiotic strains. In the course of the study, genes that provide probiotic activity were found, characterized and systematized. These genes are associated with the ability of probiotics to develop in the digestive tract of animals, the ability to attach to the intestinal walls, nutritional characteristics and antipathogenic activity, which manifests in the synthesis of low and high molecular weight metabolites.
\end{abstract}

\section{Introduction}

Probiotics are microorganisms that, when consumed, have a positive effect on the health of the host. The most commonly used probiotics are lactic acid bacteria.

Since the beginning of the discovery of probiotics, many teams of researchers have generalized their properties and identified certain criteria under which a particular microorganism can be considered a probiotic [1]: lack of pathogen properties and secreted toxins; ability to survive and develop in the digestive tract; an capability to adhesion to the walls of the intestine, which is important for the formation of colonies; stability in preparation, storage and transportation; high vitality; synthesis of antimicrobial substances, including bacteriocins, hydrogen peroxide and organic acids; ability to develop with normal intestinal microflora; resistance to gastrointestinal enzymes and bile acids; several clinically proven effects; ability to give the desired organoleptic properties to products.

\footnotetext{
*Corresponding author: nkorostylev@sfedu.ru
} 
The adaptive potential of probiotic lactobacilli includes the ability to be resistant to physical and chemical environmental factors ( $\mathrm{pH}$, bile, oxidative and osmotic stress), which is expressed in certain metabolic features (the ability to metabolize carbohydrates and other substrates); and the ability to synthesize certain proteins and other classes of high and low molecular weight substances that improve adaptive characteristics (mucin and fibronectinbinding proteins, exopolysaccharides and lipoteichoic acids, enzymes, etc.).

The object of research is a variety of probiotic microorganisms of the genus Lactobacillus and their genes that are associated with probiotic activity. These genes are responsible for survival in the gastrointestinal tract at low $\mathrm{pH}$ and a high concentration of bile acids, adhesion, production of exopolysaccharides, nutrition of bacteria in the gastrointestinal tract, immunomodulation and antipathogenic properties.

\section{Resourses}

WWWEntrez retrieval system is a system designed to work with integrated databases located in the NCBI, which contain:DNA sequences from GenBank, EMBL, DDBJ, and GSDB; protein sequences from Swiss-Prot, PIR, PRF, PDB, as well as amino acid sequences translated from nucleotide; data on the mapping of genomes and individual chromosomes;information on the tertiary structure of proteins (MMDB); bibliographic references from MEDLINE and pre-MEDLINE

Network Entrez is a client program that is installed on the local computer and provides the functions of the web version of the NCBI site, but with additional functions.

SequenceRetrievalSystem (SRS) is a service developed by EMBL to work with a large set of databases to simplify indexing, searching and retrieving data in the desired format.

NP.searcher is a resource, which according to the DNA sequence, gives the product of a possible polyketide or non-ribosomal peptide from the DNA sequence. If the whole genome is given at the input, then the clusters and their possible products are analyzed.

EuropeanGenome-phenomeArchive is an online archive that searches for genes and their products

Google Scholar is free search engine for full scientific texts of scientific publications of all formats and disciplines.

\section{Analysis of probiotic-assosiated genes of Lactobacillus}

Isolated or found throughout the GI tract, lactobacilli represent only a small fraction of the gastrointestinal microbial communities [Ошибка! Источник ссылки не найден.]. Usually lactobacilli and enterococci account for $0.01-1.8 \%$ of the total fecal microbiota, as shown by qPCR methods [Ошибка! Источник ссылки не найден.]. Their abundance in the gastrointestinal tract varies significantly from less than $10^{4} \mathrm{CFU} / \mathrm{ml}$ (small intestine) to $10^{6} \mathrm{CFU} / \mathrm{g}$ (feces) [Ошибка! Источник ссылки не найден.]. It was shown that small intestine of animals contains a diverse population of streptococci [Ошибка! Источник ссылки не найден.].

However, an analysis of the rRNA gene sequence does not allow one to determine whether these strains are endogenous or transitory. To date, more than 20 types of lactobacilli have been found in the digestive tract. Some of them are used as probiotics, such as Lactobacillus plantarum, Lactobacillus casei, or Lactobacillus rhamnosus [Ошибка! Источник ссылки не найден.].

Others are present in the oral cavity, where they can be obtained from food or be endogenous (see above). This suggests that some of the bacteria isolated from the gastrointestinal tract may come from food or the oral cavity. 
A detailed comparative and functional genomic characterization of isolates from animals can answer the question of whether they are endogenous or transit, and also help to better understand their ecological specialization, adaptation and role in their special niche. The first of these studies was associated with Lactobacillus johnsonii and Lactobacillus gasseri, which were genomically characterized ten years ago. Genomic data, supplemented by experimental work, indicate the ecological adaptation and fitness of Lactobacillus gasseri to the gastrointestinal tract, as was recently considered [Ошибка! Источник ссылки не найден.].The transcriptome analysis of Lactobacillus johnsonii NCC533 revealed a number of genes that may be associated with its persistence in the intestinal tract [Ошибка! Источник ссылки не найден.].

In a comparative genomic study of 100 Lactobacillus rhamnosus isolates some possible correlations between environmental adaptation, phenotypic traits and genomic modifications were shown. Compared to L. rhamnosus, endogenous symbiotic bacteria of other genera and types of the gastrointestinal tract also contain genes associated with specific stages of the carbon path (fructose metabolism enzymes), adhesion genes (SpaCBA - a gene cluster that determines the structure of pili), protection and systems immunity (CRISPR system) and the formation of biofilms (gene clusters that determine the structure of exopolysaccharides). They are likely to provide the ability to form colonies and preserve in the gastrointestinal tract [Ошибка! Источник ссылки не найден.].

It has been shown that intestinal isolates of Lactobacillus rhamnosus are resistant to bile, while bacteria isolated from milk, for example, are usually less resistant to bile. Two other closely related species, Lactobacillus casei and Lactobacillus paracasei, shared some LifeStyle-Specific-Islands. with Lactobacillus rhamnosus [Ошибка! Источник ссылки не найден., Ошибка! Источник ссылки не найден., Ошибка! Источник ссылки не найден.]. Using hybridization matrices and multilocus sequential typing, the genomic diversity of Lactobacillus salivarius was studied.

In accordance with the results obtained in other laboratories, intraspecific diversity was reduced to 18 chromosomal regions, which included gene clusters encoding the production of exopolysaccharides. An important factor in the probiotic potential is also the ability to produce broad-spectrum bacteriocins, which allows, for example, Lactobacillus salivarius to suppress Listeria monocytogenes [Ошибка! Источник ссылки не найден.].

In addition to chromosomal variations, the presence of plasmids and other mobile elements plays an important role. One of the remarkable examples promoting intraspecific diversity is the presence of megaplasmids in some strains of Lactobacillus salivarius. Lactobacillus salivarius subsp. salivarius UCC118 contains megaplasmid pMP118 (242 kB in size) [Ошибка! Источник ссылки не найден.]. Further analysis of two other subspecies revealed other megaplasmids of different sizes, which allows one to suggest their possible role in environmental adaptation [Ошибка! Источник ссылки не найден.].

Lactobacillus reuteri is also found frequently in various parts of the animal's body. It was shown that Lactobacillus reuteri strains in various hosts evolved, developing various adaptive characteristics. Strains isolated from various mammals, such as rodents and humans, have different genetic signatures.

Specialization is observed not only among strains of Lactobacillus reuteri, but also among strains of other symbiotic bacteria. The genomes of the intestinal Lactobacillus reuteri are usually smaller with a higher number of pseudogenes [1], as previously reported in other host-dependent bacteria [Ошибка! Источник ссылки не найден.].

Genomic analysis showed that Lactobacillus ruminis ATCC 25644 isolated from the human intestine was very similar to the strain isolated from the intestine of the bovine Lactobacillus ruminis ATCC 27782 [Ошибка! Источник ссылки не найден.]. However, they differ significantly from Lactobacillus salivarius, Lactobacillus acidophilus 
and Lactobacillus helveticus. Nevertheless, Lactobacillus helveticus tends to be more specialized in dairy environments than Lactobacillus acidophilus adapted to the intestinal environment. In the genome of Lactobacillus helveticus, adhesion factors, such as mucosebinding proteins, are absent along with the gene encoding phosphotransferase systems [Ошибка! Источник ссылки не найден., 18].

The genomic sequences of lactobacilli have become the basis for determining the secretome and interactome of lactobacilli located in the human GI tract. In the group related to the species Lactobacillus casei, the gene encoding the LPXTG protein has common features with the same gene of other lactobacilli, for example, Lactobacillus casei and Lactobacillus paracasei [19]. Among other things, clusters of pili-associated genes were identified. The maximum expression of these genes was observed in Lactobacillus rhamnosus. This contributes to the highly effective adhesion of Lactobacillus rhamnosus to the intestinal mucosa [Ошибка! Источник ссылки не найден.]. Within the species Lactobacillus rhamnosus, pili-associated genes were significantly larger and were present in intestinal isolates $(56 \%)$ compared with lactobacilli isolated from dairy products $(13 \%)$ [20].

Analysis of the genome of Lactobacillus salivarius UCC118 allowed us to identify 108 specific proteins involved in adhesion, including 10 sortase-bound proteins. Removing the genes responsible for coding for cortase-depended proteins significantly reduced the adhesive properties of Lactobacillus salivarius UCC118 [Ошибка! Источник ссылки не найден.]. Interestingly, some strains of Lactobacillus ruminis, for example, ATCC 27782, also have a set of genes associated with the functioning of the flagellar apparatus, in total 45 flagellar genes were found [22]. It has been shown that some species of lactobacilli can also affect the intestinal signaling system.

In the intestinal strain of Lactobacillus gasseri ATCC 3332, 271 proteins located on the cell surface were found and 14 of them were able to bind to the intestinal mucosa [23]. In Lactobacillus acidophilus L-92, attachment to human epithelial cells altered the expression of 78 genes that encode membrane proteins, transporters, and metabolic pathway regulators [Ошибка! Источник ссылки не найден.].

A comparative analysis of the proteome led to the identification of 18 proteins with potential adhesive properties, including proteins of the A layer. Further work showed that A-layer proteins play an important role in the adhesion of Lactobacillus acidophilus L-92 [25]. Moreover, one of the well-characterized A-layer proteins, SlpA from Lactobacillus acidophilus NCFM binds to the DC-SIGN dendritic cell receptor, indicating an effect on intestinal signaling pathways [Ошибка! Источник ссылки не найден., 27].

A number of similarities in metabolism caused by the influence of the GI tract environment are observed among probiotic species of lactobacilli. These include metabolic changes in biochemical pathways, cell wall modifications, or activation of resistance mechanisms. The mechanisms by which the expression of these genes induced by the human intestinal environment is regulated is still not fully known.

Particular attention was paid to the effects of bile salts during the presence (and possible colonization) of lactobacillus species in the GI tract. Proteome and transcriptome analysis of the intestinal L. rhamnosus GG, located in the environment of bile acids, showed activation of numerous genes associated with cell wall functions, which probably increased bacterial resistance in the digestive tract [28]. L. rhamnosus GG also had a specific reaction in response to an acidic environment, which was confirmed by proteomic analysis [29].

Similarly, in L. casei BL23, the expression of 52 genes changes when host releases bile acids, which affects the functioning of the cell wall and carbohydrate metabolism [30]. Notably, in L. acidophilus, glycogen metabolism is associated with resistance of the cell 
wall to bile acids. A study conducted on L. plantarum WCFS1 identified a set of 72 genes that began to be expressed when bacteria transferred to the gastrointestinal tract of mice [1].

These genes are mainly associated with carbohydrate metabolism, biosynthesis, and transport, among them there are four genes associated with the work of the cell wall, namely, anchor proteins [Ошибка! Источник ссылки не найден.]. L. plantarum WCFS1 is able to induce the expression of more than 400 genes located in the mucous membrane of the human small intestine [Ошибка! Источник ссылки не найден.]. In a study of mice, the transcription of L. plantarum WCFS1 gene in response to the GI environment was additionally considered [Ошибка! Источник ссылки не найден.]. What is noteworthy, the transcriptional responses of L. plantarum WCFS1 in the small intestine of humans and mice have a high number of matches [0]. It was also found that the transcriptome profile of $L$. plantarum WCFS1 was changed when exposed to p-coumaric acid, a component present in vegetables or fruits; this may signal the bacteria that it is at the entrance of the GI tract [35].

In the same way, a set of genes was studied, the expression of which increased in the presence of bile acids [Ошибка! Источник ссылки не найден.]. Within the species $L$. plantarum the strains have different sensitivity of bile, i.e., showing either resistance (strain 299v) or sensitivity (strain LC56) [36]. A comparative proteomic analysis of three different strains led to the identification of 13 proteins associated with resistance to bile acids. [37]. In addition, a change in the genes associated with cell surface proteins and metabolism suggests that. adaptation occurred upon exposure to the mouse GI tract [39].

\section{1 Genes related to adhesion}

The bacterial membrane may contain various proteins that can be attached to the cell wall and its components - lipids, peptide motifs, N- and C-ends.

SDPs Sortase-depended proteins (SDPs) are a very important group of proteins in lactic acid bacteria, which play an important role in the interaction of lactobacilli and the host. SDP is a protein attached to the membrane with a C-end, consists of a short pentapeptide motif, a hydrophobic moiety and a positively charged tail [40].

The role of sortase in the cleavage of the signal peptide after transmission from the previous sortase protein. Sortase A cleaves the signal molecule between threonine and glycine and then attaches the covalent residue to peptidoglycan (PG). Studies show that mutant forms from which the SDPs genes are removed have significantly reduced adhesion to HT-29 and Caco-2 cells. However, data on the presence of specific binding sites were not found.

Some types of lactobacilli have a special layer on the surface called the S-layer. This layer consists of protein subunits embedded in a paracrystalline hexagonal or tetragonal monolayer. Proteins of this layer usually have a small size from 40 to $60 \mathrm{kDa}$ but with a very stable tertiary structure. These proteins are non-covalently bound to the cell wall, but nevertheless stacked with high ordering. Examples of species with an S-layer: $L$. acidophilus, L. gasseri, L. johnsonii, L. brevis, L. helveticus, and L. crispatus [Ошибка!

\section{Источник ссылки не найден.].}

There are also fibronectin binding protein $(f b p \mathrm{~A})$, mucin binding protein $(\mathrm{Mub})$ and cell layer protein $(\operatorname{SlpA})$. Studies of these proteins have shown their relationship with the ability to adhere to Caco-2 cells in vitro. [Ошибка! Источник ссылки не найден.]

Genes LJ0047, LJ0484, and LJ1839 are also of interest. They encode proteins similar to a mucin-binding protein (Mub), but these proteins have other functions. Studies have 
shown that this protein is involved in the formation of fimbriae and pili [43]. Removal of these genes significantly impairs the ability to adhesion.

Lipoteichoic acids (LTAs) provide adhesion in a non-specific way. The addition of dalanine to lipoteichoic acids requires four enzymes, which are encoded by the dlt operon. Two of these genes are the d-alanine ligase (dltA), which activates d-alanine via ATP, and d-alanine, the carrier protein (-Dcp protein, dltC gene). Another protein combines LTAs and d-alanine-Dcp into a single complex.

Data on genes related to adhesion are presented in table 1.

Table 1. Genes of lactobacilli involved in adhesion.

\begin{tabular}{|c|c|c|c|c|}
\hline Organism & Gene & $\begin{array}{l}\text { Number of } \\
\text { publications }\end{array}$ & Function & Reference \\
\hline L. plantarum WCFS1 & $s r t \mathrm{~A}$ & 8050 & Sortase & {$[30]$} \\
\hline L. plantarum WCFS1 & $m s a$ & 3120 & $\begin{array}{c}\text { Mannose-specific } \\
\text { adhesin }\end{array}$ & {$[30]$} \\
\hline L. plantarum WCFS1 & lp_2940 & 47 & \multirow{2}{*}{$\begin{array}{l}\text { Sortase-dependent } \\
\text { cell wallprotein }\end{array}$} & {$[20]$} \\
\hline $\begin{array}{l}\text { L. plantarum } \\
\text { WCFS1 }\end{array}$ & lp_1403 & 27 & & {$[20]$} \\
\hline L. acidophilus NCFM & $f b p \mathrm{~A}$ & 3590 & $\begin{array}{l}\text { Fibronectin- } \\
\text { bindingprotein }\end{array}$ & $\begin{array}{c}\text { [Ошибка! } \\
\text { Источник } \\
\text { ссылки } \\
\text { не } \\
\text { найден.] }\end{array}$ \\
\hline L. acidophilus NCFM & mub & 28800 & $\begin{array}{l}\text { Mucus-binding } \\
\text { protein }\end{array}$ & $\begin{array}{c}\text { [Ошибка! } \\
\text { Источник } \\
\text { ссылки } \\
\text { не } \\
\text { найден.] }\end{array}$ \\
\hline L. acidophilus NCFM & $\operatorname{slp} \mathrm{A}$ & 2170 & S-layer protein & $\begin{array}{c}\text { [Ошибка! } \\
\text { Источник } \\
\text { ссылки } \\
\text { не } \\
\text { найден.] }\end{array}$ \\
\hline L. acidophilus NCFM & $c d p \mathrm{~A}$ & 6620 & $\begin{array}{c}\text { Cell-wall } \\
\text { modifying protein } \\
\text { involved in cell } \\
\text { devison }\end{array}$ & $\begin{array}{c}\text { [Ошибка! } \\
\text { Источник } \\
\text { ссылки } \\
\text { не } \\
\text { найден.] }\end{array}$ \\
\hline L. acidophilus NCFM & $\begin{array}{l}\text { LBA1663- } \\
\text { LBA1664 }\end{array}$ & 15 & R28 gamolog & $\begin{array}{c}\text { [Ошибка! } \\
\text { Источник } \\
\text { ссылки } \\
\text { не } \\
\text { найден.] }\end{array}$ \\
\hline
\end{tabular}




\begin{tabular}{|c|c|c|c|c|}
\hline \multirow{2}{*}{ L. salivarius UCC118 } & $\operatorname{srt\mathrm {A}}$ & 8050 & Sortase & $\begin{array}{c}\text { [Ошибка! } \\
\text { Источник } \\
\text { ссылки } \\
\text { не } \\
\text { найден.] }\end{array}$ \\
\hline & $\begin{array}{c}l s p \mathrm{~A} \\
l s p \mathrm{~B}, l s p \mathrm{D}\end{array}$ & 8150 & $\begin{array}{l}\text { Large surface } \\
\text { protein, mucose- } \\
\text { specific biding }\end{array}$ & $\begin{array}{c}\text { [Ошибка! } \\
\text { Источник } \\
\text { ссылки } \\
\text { не } \\
\text { найден.] }\end{array}$ \\
\hline L. reuteri $100-23$ & $l s p$ & 243 & $\begin{array}{l}\text { Large surface } \\
\text { protein }\end{array}$ & {$[44]$} \\
\hline L. johnsonii NCC533 & LJ1476 & 81 & $\begin{array}{c}\text { Transport and } \\
\text { sortase activity }\end{array}$ & {$[45]$} \\
\hline L. rhamnosus GG & dltD & 1920 & \multirow{2}{*}{$\begin{array}{c}\text { d-Alfnin } \\
\text { attachment to LTA }\end{array}$} & {$[46]$} \\
\hline L. reuteri $100-23$ & $d l t \mathrm{~A}$ & 7980 & & {$[47]$} \\
\hline L. johnsonii NCC533 & $\begin{array}{l}\text { LJ1021- } \\
\text { LJ1035 }\end{array}$ & 807 & Larg EPS claster & {$[45]$} \\
\hline L. plantarum WCFS1 & $\operatorname{lam} \mathrm{A}$ & 53300 & $\begin{array}{l}\text { Response regulator } \\
\text { of a } 2 \text { CRS for EPS }\end{array}$ & {$[48]$} \\
\hline L. rhamnosus GG & $w z b$ & 6240 & $\begin{array}{c}\text { EPS } \\
\text { phosphotyrosine } \\
\text { phosphatase }\end{array}$ & {$[46]$} \\
\hline L. reuteri TMW 1.106 & inu & 26300 & Inulosucrase & [44] \\
\hline L. reuteri TMW1.106 & $g t f \mathrm{~A}$ & 2010 & Glucosyltransferase & {$[44]$} \\
\hline
\end{tabular}

\section{2 Genes related to stress}

Studies show that low $\mathrm{pH}$ and bile acids can cause irreversible changes in the cell membrane. There are genes whose removal in mutant strains leads to a decrease in resistance at low $\mathrm{pH}$ and at a high concentration of bile acids, which leads to the accumulation of stress agents.

Genes associated with peptidoglycan synthesis increase survival in intestinal medium. For example, the $\operatorname{lr} 1516$ esterase gene, which belongs to the penicillin-binding protein family, increases resistance to low $\mathrm{pH}$ [49]. SrtA is a gene encoding an S-layer protein; when it is removed, resistance to bile acids decreases [50]. The $c d p \mathrm{~A}$ gene encodes a protein associated with the division and separation of daughter cells from each other. When removed, resistance to low $\mathrm{pH}$ decreases.

The role of exopolysaccharides in resistance to low $\mathrm{pH}$ and bile acids. The eps $\mathrm{B}$, eps $\mathrm{C}$, and epsE genes were found in L. acidophilus and $1 \mathrm{r} 0957$ in L. reuteri, respectively [51]. Eps $\mathrm{E}$ encodes a glycosyltransferase, which transfers glucose monomer for further synthesis of polysaccharides. However, the role of this gene has not yet been sufficiently investigated. But there is evidence that the absence of $\operatorname{lr} 1516$ in mutant strains leads to a decrease in resistance to bile acids.

There are special proteins that protect DNA and other proteins from damage caused by components of the intestinal environment. An increase in the expression of genes associated with DNA repair was shown after bacteria were exposed to low $\mathrm{pH}$ or bile acids. For example, the expression of the unrA gene of $L$. helveticus CNBL 1156, the gene of subunit of ATP-binding cassette transporters involved in the excision repair of base pairs with increasing acidity of the medium, increases [52]. Also, the concentration of $L$. reuteri dps 
gene product in an environment with bile acids increases. This gene is activated when there is a lack of nutrients. Its beneficial effect is possibly associated with the repair of DNA and enzymes.

In addition to DNA repair genes, chaperones also increase their expression: GroES, GroEL, DnaK,DnaJ, GrpE, GroES and GroEL, which begin to be synthesized in $L$. acidophilus in response to an increase in acidity. These proteins are encoded by homonymous genes of L. acidophilus and are the main with prolonged exposure to such conditions. The degradation of abnormal proteins is carried out using serine peptidase. Its component Clp ATPase begins to be actively synthesized when the cell enters stressful conditions. It has been proven that disabling the $\operatorname{clp} \mathrm{L}, c l p \mathrm{E}$, and $c l p \mathrm{C}$ genes decreases the survival of $L$. reuteri cells within the gastrointestinal tract of mice [49].

The expression of the $m s r \mathrm{~B}$ gene of methionyl sulfoxide reductase in $L$. reuteri increases when bacteria enter the gastrointestinal tract of mice. [53] This enzyme protects cell against oxidative stress by converting methionine to methionine sulfoxide. Removal of this gene leads to a decrease in cell survival in the gastrointestinal tract of mice.

There are two-component regulatory systems (2CRSs) that can detect stress factors in the environment and respond to them in advance using a cascade of transmembrane histidine kinases. Removal of the histidine kinase gene or 2CRSs genes (LBA1524LBA1525) in L. acidophilus NCFM results in reduced survival in the gastrointestinal tract of mice [Ошибка! Источник ссылки не найден.].

In addition to resistance to stress factors and the need for repair, the cell also needs mechanisms to remove stress agents. For example, the expression of ATP synthase genes increases when cells of the species L. acidophilus, L. rhamnosus, and L. plantarum are found at low $\mathrm{pH}$. Studies with mutant forms have not been conducted, but there are studies that show an increase in the expression of glucose catabolism genes. Perhaps this is due to an increase in the concentration of protons in the cytoplasm. In addition to this ATP synthase gene, an increase in the expression of the copper transport ATPase (copA) gene was proved in L. bulgaricus ATCC 11842 and L. johnsonii NCC533 [Ошибка! Источник ссылки не найден.]. Data on mutant forms were not found.

Another mechanism affecting resistance to low $\mathrm{pH}$ and bile acids is the reaction of converting arginine to ornithine, ammonia, and carbon dioxide. Three enzymes catalyze this reaction: arginine deiminase, ornithine transcarbamylase and carbamate kinase $\operatorname{arc} \mathrm{A}$, $\operatorname{arc} \mathrm{B}$ and $\operatorname{arc} \mathrm{C}$, respectively. Studies have shown that the expression of these genes increases when L. reuteriATCC 55730 cells are present in a bile acid medium [55].

Lactobacilli have developed a specific mechanism for the transport and hydrolysis of bile acids. This system belongs to the multidrug resistance system (MDR). MDR has similarities to a two-component response system. In studies, two transporter enzymes were found that provide resistance to bile acids. They are encoded by the genes: $\operatorname{lr} 1265$ and $1 \mathrm{1} 1584$, the expression of which increases after processing of L. reuteri 27 ATCC 55730 cells, bile acids. Mutants are not able to survive in an environment with bile acids.

Some bacteria are able to modify bile acids using bile acid hydrolases (BSHs - bile salt hydrolases), which are mostly intracellular enzymes. They catalyze the hydrolysis of the amide bond between the steroid moiety and the amino acid side chain. These enzymes were isolated only from microorganisms inhabiting the human gastrointestinal tract ( $L$. acidophilus, L. gasseri, L. johnsonii, and L. plantarum). Genes encoding these enzymes: $b s h \mathrm{~A}, b s h \mathrm{~B}$ and $b s h 1$. When these genes are disabled, cell survival in the digestive tract decreases [56].

Data on genes related to stress reactions are presented in table 2.

Table 2. Genes of lactobacilli involved in stress reaction. 


\begin{tabular}{|c|c|c|c|c|}
\hline Organism & Gene & $\begin{array}{l}\text { Number of } \\
\text { publications }\end{array}$ & Function & Reference \\
\hline $\begin{array}{l}\text { L. reuteri } \mathrm{ATCC} \\
55730\end{array}$ & $\operatorname{lr} 1516$ & 50 & $\begin{array}{c}\text { Esterase involved in PG } \\
\text { biosynthesis and reorganization }\end{array}$ & [57] \\
\hline L. acidophilus NCFM & $\begin{array}{l}\text { LBA127 } \\
2\end{array}$ & 13 & $\begin{array}{l}\text { Cyclopropane fatty acid } \\
\text { synthase }\end{array}$ & [58] \\
\hline L. rhamnosus GG & $d l t \mathrm{D}$ & 1920 & \multirow[t]{2}{*}{ d-Alanylation of LTA } & [46] \\
\hline L. reuteri $100-23$ & dlt A & 7980 & & [59] \\
\hline \multirow[t]{2}{*}{ L. acidophilus NCFM } & slp $\mathrm{A}$ & 1150 & S-layer protein & {$[30]$} \\
\hline & $c d p \mathrm{~A}$ & 811 & $\begin{array}{l}\text { Cell division and separation } \\
\text { protein }\end{array}$ & [30] \\
\hline \multirow{3}{*}{$\begin{array}{l}\text { L. reuteri ATCC } \\
55730\end{array}$} & dps & 46000 & $\begin{array}{c}\text { DNA protection during } \\
\text { starvation }\end{array}$ & [60] \\
\hline & $\operatorname{clpL}$ & 6980 & Clp ATPase & {$[60]$} \\
\hline & $\operatorname{clp} \mathrm{E}$ & 5720 & \multirow{2}{*}{ Clp ATPase } & {$[60]$} \\
\hline L. plantarum WCFS1 & $\operatorname{clpC}$ & 5130 & & {$[61]$} \\
\hline L. reuteri $100-23$ & $m s r \mathrm{~B}$ & 5330 & Methionine sulfoxide reductase & [62] \\
\hline L. rhamnosus GG & $\operatorname{lu} x \mathrm{~S}$ & 11900 & Activated methyl cycle & [61] \\
\hline \multirow{4}{*}{ L. acidophilus NCFM } & $\begin{array}{c}\text { LBA152 } \\
4\end{array}$ & 21 & \multirow{2}{*}{ Histidine protein kinase } & [63] \\
\hline & $\begin{array}{c}\text { LBA143 } \\
0\end{array}$ & 15 & & [63] \\
\hline & $\begin{array}{c}\text { LBA143 } \\
1\end{array}$ & 15 & Response regulato & [63] \\
\hline & $\begin{array}{l}\text { LBA143 } \\
2\end{array}$ & 15 & $\begin{array}{c}\text { Protein with similarity to } \\
\text { RelA/SpoT }\end{array}$ & [63] \\
\hline \multirow{2}{*}{ L. sakei $23 \mathrm{~K}$} & rrp-1 & 2150 & Response regulator & {$[64]$} \\
\hline & rrp-48 & 49 & Response regulator & [64] \\
\hline \multirow{4}{*}{ L. acidophilus NCFM } & \multirow{2}{*}{$\operatorname{gad} \mathrm{C}$} & \multirow{2}{*}{5270} & Glutamate/ & \multirow{2}{*}{$\begin{array}{c}\text { [Ошибка } \\
! \\
\text { Источни } \\
\text { к } \\
\text { ссылки } \\
\text { не } \\
\text { найден.] } \\
\end{array}$} \\
\hline & & & -aminobutyrate antip & \\
\hline & $\begin{array}{l}\text { LBA086 } \\
7\end{array}$ & 3 & Transcriptional regulator & $\begin{array}{c}\text { [Ошибка } \\
! \\
\text { Источни } \\
\text { к } \\
\text { ссылки } \\
\text { не } \\
\text { найден.] }\end{array}$ \\
\hline & LBA099 & 6 & Amino acid permease & [Ошибка \\
\hline
\end{tabular}




\begin{tabular}{|c|c|c|c|c|}
\hline Organism & Gene & $\begin{array}{l}\text { Number of } \\
\text { publications }\end{array}$ & Function & Reference \\
\hline & 5 & & & $\begin{array}{c}! \\
\text { Источни } \\
\text { к } \\
\text { ссылки } \\
\text { не } \\
\text { найден.] }\end{array}$ \\
\hline & $\begin{array}{c}\text { LBA099 } \\
6\end{array}$ & 3 & Ornithine decarboxylase & $\begin{array}{c}\text { [Ошибка } \\
! \\
\text { Источни } \\
\text { к } \\
\text { ссылки } \\
\text { не } \\
\text { найден.] } \\
\end{array}$ \\
\hline \multirow[t]{2}{*}{$\begin{array}{c}\text { L. reuteri ATCC } \\
55730\end{array}$} & Lr1265 & 41 & $\begin{array}{c}\text { Multidrug resistance protein } \\
\text { (ABC } \\
\text { transporter family) }\end{array}$ & {$[60]$} \\
\hline & Lr1584 & 30 & MDR protein & {$[60]$} \\
\hline \multirow{3}{*}{ L. acidophilus NCFM } & $\begin{array}{c}\text { LBA142 } \\
7\end{array}$ & 11 & \multirow{2}{*}{ Oxidoreductase } & [63] \\
\hline & $\begin{array}{c}\text { LBA142 } \\
8\end{array}$ & 5 & & {$[63]$} \\
\hline & $\begin{array}{c}\text { LBA142 } \\
9\end{array}$ & 23 & MBR protein & {$[63]$} \\
\hline \multirow{5}{*}{ L. acidophilus NCFM } & $b \operatorname{sh} \mathrm{A}$ & 1240 & \multirow{6}{*}{ Bile salt hydrolase } & $\begin{array}{c}\text { [Ошибка } \\
! \\
\text { Источни } \\
\text { к } \\
\text { ссылки } \\
\text { не } \\
\text { найден.] } \\
\end{array}$ \\
\hline & $b \operatorname{sh} \mathrm{B}$ & 871 & & $\begin{array}{c}\text { [Ошибка } \\
! \\
\text { Источни } \\
\text { к } \\
\text { ссылки } \\
\text { не } \\
\text { найден.] }\end{array}$ \\
\hline & LJ0056 & 13 & & \multirow{3}{*}{$\begin{array}{c}\text { [Ошибка } \\
! \\
\text { Источни } \\
\text { к } \\
\text { ссылки } \\
\text { не } \\
\text { найден.] }\end{array}$} \\
\hline & LJ1147 & 739 & & \\
\hline & LJ1413 & 162 & & \\
\hline L. plantarum WCFS1 & $b s h 1$ & 2490 & & $\begin{array}{c}\text { [Ошибка } \\
! \\
\text { Источни } \\
\text { к } \\
\text { ссылки } \\
\text { не } \\
\text { найден.] }\end{array}$ \\
\hline
\end{tabular}




\subsection{Genes related to nutrition}

In addition to the need to adapt to the living conditions of the host, it is necessary to absorb nutrients from the digestive tract. The main source of carbohydrates for lactic acid bacteria is sugars, which prevail in the upper GI tract and indigestible complex carbohydrates, which prevail in the lower intestine.

Among lactic acid bacteria, the phosphotransferase system plays a very important role, which serves to transfer sugar into the bacterial cell, since lactic acid bacteria are auxotrophs - organisms that are not able to synthesize the substances they need: amino acids, vitamins, enzyme cofactors. The following genes encode this enzyme: LJ1654LJ1656. Analysis of mutant forms of L. johnsonii NCC533 showed a decrease in survival in the gastrointestinal tract of mice. In L. johnsonii NCC533 in the small intestine of mice, the expression of four phosphotransferases increases at once: for fructose, glucose, cellobiose, and galactosamine, along with this, the expression of enzymes that metabolize sugar 40 increases. Thus, this proves that sugar transporters are very important in the small intestine for probiotics of the genus Lactobacillus [Ошибка! Источник ссылки не

\section{найден.].}

In the genome of L. acidophilus NCFM, a large number of genes have been found encoding transfer enzymes and enzymes that metabolize sugars, mono-, di- and polysaccharides, for example, raffinose and fructooligoplisaccharides. For each carbohydrate, either phosphotransferases or ATP-binding cassette transporters exist. There is evidence that these systems are associated with protection against cold and osmotic stress [22]. L. acidophilus NCFM has 20 phosphotransferases. This set of enzymes allows $L$. acidophilus NCFM, unlike L. johnsonii NCC53, to exist in areas of the intestine with a lower nutrient content. In L. plantarum WCFS1, 25 phosphotransferases were found.

In $L$. reuteri the xyloseisomerase gene was found. A bacterium is capable of detecting its presence in the intestine; then xylose metabolized into xylulose.

Data on genes involved in nutrition are presented in table 3.

Table 3. Genes of lactobacilli involved in nutrition.

\begin{tabular}{|c|c|c|c|c|}
\hline Organism & Gene & $\begin{array}{c}\text { Number of } \\
\text { publications }\end{array}$ & Function & Reference \\
\hline L. johnsonii NCC533 & $\begin{array}{l}\text { LJ1654- } \\
\text { LJ1656 }\end{array}$ & $30,45,10$ & $\begin{array}{l}\text { PTS sugar } \\
\text { transporter }\end{array}$ & {$[66]$} \\
\hline L. plantarum WCFS1 & pts $14 \mathrm{C}$ & 17 & $\begin{array}{c}\text { Cellobiose PTS, } \\
\text { EIIC }\end{array}$ & {$[61]$} \\
\hline L. reuteri $100-23$ & xylA & 13000 & Xylose isomerase & {$[62]$} \\
\hline \multirow[b]{2}{*}{ L. reuteri TMW1.106 } & inu & 26300 & Inulosucrase & {$[67]$} \\
\hline & $g t f \mathrm{~A}$ & 1870 & $\begin{array}{c}\text { Glucosyltransfera } \\
\text { se }\end{array}$ & {$[67]$} \\
\hline \multirow{3}{*}{ L. acidophilus NCFM } & $b f r \mathrm{~A}$ & 58400 & $\begin{array}{l}\text { Intracellular - } \\
\text { fructosidase }\end{array}$ & {$[68]$} \\
\hline & $m s m \mathrm{E}$ & 3120 & $\begin{array}{l}\text { ABC transporter } \\
\text { substrate } \\
\text { binding protein }\end{array}$ & {$[68]$} \\
\hline & fos $\mathrm{E}$ & 3120 & $\begin{array}{l}\text { Extracellular - } \\
\text { fructosidase }\end{array}$ & $\begin{array}{c}\text { [Ошибка } \\
! \\
\text { Источни } \\
\text { к } \\
\text { ссылки } \\
\end{array}$ \\
\hline
\end{tabular}




\begin{tabular}{|c|c|c|c|c|}
\hline & & & & $\begin{array}{c}\text { не } \\
\text { найден.] }\end{array}$ \\
\cline { 2 - 5 } & treC & 14700 & Trehalase & $\begin{array}{c}\text { [Ошибка } \\
\text { Источни } \\
\text { к } \\
\text { ссылки } \\
\text { не } \\
\text { найден.] }\end{array}$ \\
\hline L. johnsonii NCC533 & prtP & 4290 & $\begin{array}{c}\text { Cell wall-bound } \\
\text { proteinase }\end{array}$ & \begin{tabular}{c} 
[66] \\
\hline L. reuteri 100-23
\end{tabular} \\
& met & 29000 & $\begin{array}{c}\text { Methionine } \\
\text { synthase }\end{array}$ & {$[62]$} \\
\hline
\end{tabular}

\subsection{Bacteriocins of lactic acid bacteria}

Some of the lactobacilli produce bacteriocins, antibacterial protein substances with bactericidal activity against related species (narrow spectrum) or other genera (wide spectrum of action). Bacteriocin biosynthesis is an important characteristic for the selection of a probiotic strain, since it provides mechanisms for the inhibition of pathogens in fermented foods and in the GI tract.

Bacteriocins are ribosomally synthesized peptides or proteins with antimicrobial activity, obtained by many gram-positive and gram-negative bacteria; bacteriocins, however, produced by food strains of lactobacilli have received considerable attention because of their possible use in the food industry as natural preservatives (biopreservatives).

Bacteriocins produced by lactobacilli, small antimicrobial peptides or proteins that are active against closely related gram-positive bacteria, while producer cells are immune to their own bacteriocins [25]. There are several generally accepted classifications of bacteriocins in which these antimicrobial substances are divided into 3 or 4 classes: Class I - lantibiotics or small, thermostable, lanthionine-containing, one- and two-peptide bacteriocins, which undergo extensive post biologically inactive to obtain the necessary properties - translational modification; class II - small, thermostable, lanthionine-free bacteriocins, including pediocin-like or anti-genus Listeria bacteriocins (class IIa), dipeptide bacteriocins (class IIb), and circular bacteriocins (class IIc); Class III bacteriocins are large, thermolabile, lytic proteins that are often peptidoglycan hydrolases (class III) [Ошибка! Источник ссылки не найден.] also offer class IV bacteriocins that require non-protein fragments (lipids, carbohydrates) for their activity.

Data on genes involved in bacteriocins synthesis are presented in table 4.

Table 4. Genes of bacteriocins synthesized by lactobacilli.

\begin{tabular}{|c|c|c|c|c|c|}
\hline Peptide & Gene & $\begin{array}{c}\text { Number } \\
\text { of } \\
\text { publicati } \\
\text { ons }\end{array}$ & Organism (plasmid) & $\begin{array}{c}\text { Genebank } \\
\text { number }\end{array}$ & References \\
\hline \multicolumn{3}{|c|}{ Class I } \\
\hline
\end{tabular}




\begin{tabular}{|c|c|c|c|c|c|}
\hline Lactocin $\mathrm{S}$ & $\operatorname{las} \mathrm{A}$ & 941 & L.sake L45 (pCIM1) & $\underline{X 79889}$ & $\begin{array}{c}\text { [Ошибка! } \\
\text { Источник } \\
\text { ссылки не } \\
\text { найден.] }\end{array}$ \\
\hline \multicolumn{6}{|c|}{ Class II } \\
\hline \multicolumn{6}{|c|}{ Type A } \\
\hline Sakacin A & $\operatorname{sap} \mathrm{T}$ & 360 & L. sake b706 & $\underline{Z} 46867$ & {$[71,72,73]$} \\
\hline Sakacin P & sppA & 165 & L. curvatus LTH1174 & $\underline{\mathrm{DQ} 019413}$ & [74] \\
\hline $\begin{array}{c}\text { Curvacin } \\
\text { A }\end{array}$ & curA & 598 & L. curvatus LTH1174 & $\underline{\text { S67323 }}$ & {$[74]$} \\
\hline $\begin{array}{c}\text { Leucocin } \\
\mathrm{K}\end{array}$ & $\begin{array}{c}p p n \mathrm{C} \\
7\end{array}$ & 22 & L. paraplantarum $C 7$ & $\frac{\mathrm{AF} 420260 .}{\underline{1}}$ & {$[75]$} \\
\hline $\begin{array}{l}\text { Pediocin } \\
\text { AcH }\end{array}$ & papA & 1120 & $\begin{array}{l}\text { L. plantarum WHE } 92 \\
\text { (pWHE92) }\end{array}$ & $\frac{\mathrm{AY} 316526}{\underline{.1}}$ & $\begin{array}{c}\text { [Ошибка! } \\
\text { Источник } \\
\text { ссылки не } \\
\text { найден.] }\end{array}$ \\
\hline \multicolumn{6}{|c|}{ TybeB } \\
\hline Lacticin F & Laf & 303 & L. acidophilus NCK88 & $\underline{\text { M57961 }}$ & {$[76]$} \\
\hline \multirow{5}{*}{$\begin{array}{l}\text { Lactococci } \\
\quad n \text { G }\end{array}$} & $\operatorname{lag} \mathrm{A}$ & 95 & \multirow{5}{*}{ L.lactis LMGT 2081} & \multirow{5}{*}{$\underline{\text { FJ938036 }}$} & \multirow{5}{*}[77]{} \\
\hline & $\operatorname{lag} \mathrm{B}$ & 22 & & & \\
\hline & $\operatorname{lag} \mathrm{C}$ & 26 & & & \\
\hline & $\operatorname{lag} \mathrm{D}$ & 64 & & & \\
\hline & $\operatorname{lag} \mathrm{E}$ & 661 & & & \\
\hline $\begin{array}{l}\text { Plantaricin } \\
\text { P }\end{array}$ & $\begin{array}{l}\text { Plnlo } \\
\text { cus }{ }^{1} \\
1900 \\
0 \text { bp }\end{array}$ & 548 & L. plantarum & $\frac{\text { BAV8299 }}{\underline{4.1}}$ & $\begin{array}{c}\text { [Ошибка! } \\
\text { Источник } \\
\text { ссылки не } \\
\text { найден.] } \\
\end{array}$ \\
\hline \multirow[b]{2}{*}{$\begin{array}{c}\text { Gassericin } \\
\mathrm{T}\end{array}$} & \multirow[b]{2}{*}{$\operatorname{gat} \mathrm{T}}$, & \multirow[b]{2}{*}{142} & L. gasseri LA327 & $\frac{\text { LC389592. }}{1}$ & [79] \\
\hline & & & L. gasseri SB2055 & Not found & $\begin{array}{c}\text { [Ошибка! } \\
\text { Источник } \\
\text { ссылки не } \\
\text { найден.] }\end{array}$ \\
\hline $\begin{array}{l}\text { Gassericin } \\
\mathrm{K}\end{array}$ & $\begin{array}{c}\text { gas } \mathrm{A}, \\
\operatorname{gas} \mathrm{X}, \\
\operatorname{gas} \mathrm{I} \\
1143 \\
\mathrm{bp}\end{array}$ & & L. gasseri LA327 & $\frac{\mathrm{LC} 389591 .}{\underline{1}}$ & $\begin{array}{c}\text { [Ошибка! } \\
\text { Источник } \\
\text { ссылки не } \\
\text { найден.] }\end{array}$ \\
\hline \multicolumn{6}{|c|}{ TypeC } \\
\hline $\begin{array}{l}\text { Acidocin } \\
\text { A }\end{array}$ & $\begin{array}{c}a c d \mathrm{~A} \\
4500 \\
\mathrm{bp} \\
\end{array}$ & 21 & L. acidophilus TK9201 & $\frac{\text { BAA0712 }}{\underline{0.1}}$ & {$[81]$} \\
\hline Acidocin B & $\begin{array}{c}a c d \mathrm{~B} \\
2200 \\
\mathrm{bp}\end{array}$ & 31 & $\begin{array}{l}\text { L. acidophilus M46 } \\
\text { (pLA103, pLA103) }\end{array}$ & $\underline{Z 34920.1}$ & $\begin{array}{l}\text { [Ошибка! } \\
\text { Источник } \\
\text { ссылки не }\end{array}$ \\
\hline
\end{tabular}




\begin{tabular}{|c|c|c|c|c|c|}
\hline & & & & & найден.] \\
\hline $\begin{array}{l}\text { acidocin } \\
\text { LF221 A }\end{array}$ & $\begin{array}{l}858 \\
b p\end{array}$ & 3 & L. gasseri LF221 & AY295874 & $\begin{array}{c}\text { [Ошибка! } \\
\text { Источник } \\
\text { ссылки не } \\
\text { найден.,О } \\
\text { шибка! } \\
\text { Источник } \\
\text { ссылки не } \\
\text { найден.] }\end{array}$ \\
\hline $\begin{array}{l}\text { acidocin } \\
\text { LF221 B }\end{array}$ & $\begin{array}{c}1772 \\
\text { bp }\end{array}$ & 2 & L. gasseri LF221 & $\frac{\mathrm{AY} 297947}{.1}$ & $\begin{array}{c}\text { [Ошибка! } \\
\text { Источник } \\
\text { ссылки не } \\
\text { найден., } \\
\text { 84] }\end{array}$ \\
\hline $\begin{array}{c}\text { Gassericin } \\
\text { E }\end{array}$ & $\begin{array}{c}\text { gas } \mathrm{E} \\
\text { locus }^{2} \\
6188 \\
\text { bp }\end{array}$ & 95 & L. gasseri EV1461 & $\frac{\mathrm{KR} 080485}{\underline{.1}}$ & $\begin{array}{c}\text { [Ошибка! } \\
\text { Источник } \\
\text { ссылки не } \\
\text { найден.] }\end{array}$ \\
\hline \multicolumn{6}{|c|}{ Class III } \\
\hline $\begin{array}{c}\text { Enterolysi } \\
\mathrm{n} \mathrm{A}\end{array}$ & entA & 578 & L. helveticus ${ }^{3}$ & $\frac{\text { AYE61478 }}{.1}$ & [49] \\
\hline $\begin{array}{c}\text { Helveticin } \\
\mathrm{J}\end{array}$ & hlvJ & 7 & $\begin{array}{l}\text { Lactobacillus } \\
\text { helveticus } 481\end{array}$ & M59360.1 & {$[85]$} \\
\hline \multicolumn{6}{|c|}{ Class IV } \\
\hline $\begin{array}{c}\text { Plantaricin } \\
\text { S }\end{array}$ & $\begin{array}{l}p l s \mathrm{~A}, \\
p l s \mathrm{~B}\end{array}$ & 30 & L. plantarum LPCO10 & $\underline{Y 15127.1}$ & {$[53]$} \\
\hline \multirow[b]{2}{*}{$\begin{array}{c}\text { Gassericin } \\
\text { A }\end{array}$} & $g a a \mathrm{~A}$ & 85 & $\begin{array}{l}\text { L. gasseri LA39 } \\
(p L g L A 39)\end{array}$ & $\frac{\mathrm{BAH} 0871}{2.1}$ & {$[86]$} \\
\hline & $g a a \mathrm{~A}$ & 85 & $\begin{array}{l}\text { L. paracasei } S D 1 \\
(p S D 1)\end{array}$ & Not found & $\begin{array}{c}\text { [Ошибка! } \\
\text { Источник } \\
\text { ссылки не } \\
\text { найден.] }\end{array}$ \\
\hline
\end{tabular}

${ }^{\mathrm{T}}$ There are 27 genes in the locus that are combined among 33 strains L. Plantarum DOI $10.1007 / \mathrm{s} 12602-017-9336-0$

${ }^{2}$ The presence of two operons that are involved in biosynthesis and immunity, as well as in the regulation, transport and metabolism of bacteriocin. DOI 10.1186/s12866-016-0663-1

${ }^{3}$ Enterolysin A was detected in 8 strains of L. helveticus DOI 10.3389/fmicb.2019.01380

\section{Discussion}

The genes found and their products make it possible to evaluate which probiotic activity is associated with bacterial cell structures and physiological mechanisms. Also, the number of publications on a particular gene indicates not only its popularity as an object of study. It can be assumed that this gene is distributed not only among the Lactobacillus genus. It is necessary to continue research and determine in which systematic group this gene occurs: either in the whole family of microorganisms or in only one species. The largest number of publications was found for the following genes: $m u b$ (28 00 publications), which determines specific binding to the mucous membrane: dps (46 000), associated with the 
protection of DNA during fasting; lumA (53,300 publications), 2CRS response regulator for EPS and membrane proteins; inu (26,300 publications), inulsucrase.

According to the study, the bacteriocins of the second class are mostly responsible for the antipathogenic activity of the genus Lactobacillus. Here, research needs to be continued in the direction of genetic engineering and the introduction of bacteriocin genes into bacteria whose wild forms cannot synthesize this bacteriocin.

A promising development of research in this direction is the introduction of bacteriocin genes by genetic engineering into bacteria whose wild types cannot synthesize this bacteriocin. This approach will increase the spectrum of probiotic activity of a specific bacterial strain, which will increase the effectiveness of probiotic preparations.

The systematization of these genes can become the basis for the development of test systems and databases for genetic screening, allowing the selection of promising probiotic strains using molecular genetic methods, which will significantly reduce the time of such selection compared to traditional methods.

\section{Conclusions}

Probiotic strains of the genus Lactobacillus are a very important component of the microflora of animals and humans. Their study is relevant for veterinary medicine. Of particular interest are not only their beneficial effects on host health, but also the genetic and biochemical mechanisms that provide probiotic activity. A study of the genetics of probiotic organisms will contribute to the creation and improvement of probiotic drugs.

In this study, genes that provide probiotic activity in its most striking aspects were summarized. These genes are associated with the ability of probiotics to develop in the host's gastrointestinal tract, have resistance to low $\mathrm{pH}$ and bile acids, adhesion to intestinal walls, nutritional characteristics and antipathogenic activity, which consists in the synthesis of low and high molecular weight substances.

Further search and systematization of these genes will continue, which will affect the improvement of probiotic drugs, and therefore, animal health.

Authors acknowledge the support of the Government of the Russian Federation (contract No. 075-152019-1880).

\section{References}

1. P. A. Bron, M. Marco, S. M. Hoffer, E. Van Mullekom, W. M. De Vos, M. Kleerebezem, Journal of bacteriology, 186, 7829 (2004)

2. P. Louis, K. P. Scott, S. H. Duncan, H. J. Flint Journal of applied microbiology, 102, 1197 (2012)

3. E. G. Zoetendal, J. Raes, B. Van Den Bogert, M. Arumugam, C. C. Booijink, F. J. Troost, M. Kleerebezem, The ISME journal, 6, 1415 (2012)

4. B. V.den Bogert, O. Erkus, J. Boekhorst, M. D., E. J. Goffau, E. G. Zoetendal, M. Kleerebezem, 85, 376 (2013)

5. T. Vesa, P. Pochart, P. Marteau Alimentary pharmacology \& therapeutics, 14, 823 (2000)

6. K. Selle, T. R. Klaenhammer FEMS microbiology reviews, 37, 915 (2013)

7. E. Denou, R. D. Pridmore, B. Berger, J. M. Panoff, F. Arigoni, H. Brüssow Journal of bacteriology 190, 3161 (2008) 
8. H. Cai, B. T. Rodriguez, W. Zhang, J. R. Broadbent, J. L. Steele, Microbiology, 153, 2655 (2007)

9. F. P. Kant, T. E. Pietilä, H. M. Järvinen, M. Messing, C. Caggia. PLoS Genet 9, e1003683 (2013)

10. E. J. Raftis, E. Salvetti, S. Torriani, G. E. Felis, P. W. O'Toole. Applied and environmental microbiology, 77, 954, (2011)

11. S. C. Corr, Y. Li, C. U. Riedel, P. W. O'Toole, C. Hill, C. G. Gahan, Proceedings of the National Academy of Sciences, 104, 7617, (2007)

12. M. J. Claesson, Y. Li, S. Leahy, C. Canchaya, J. P.van Pijkeren, A. M. CerdeñoTárraga, D. Higgins, Current opinion in genetics \& development, 103, 6718 (2006)

13. S. Naito, H. Hayashidani, K. Kaneko, M. Ogawa, Y. Benno, Journal of Applied Bacteriology, 79, 230 (1995)

14. N. A. Moran, G. R. Plague, Current opinion in genetics \& development, 14, 627 (2004)

15. B. M. Forde, B. A. Neville, M. M. O’Donnell, E. Riboulet-Bisson, M. J. Claesson, A. Coghlan, P. W. O'Toole, In Microbial cell factories, 10, s13, (2011)

16. P. A. Vandenbergh, FEMS Microbiology Reviews, 12, 221 (1993)

17. E. Altermann, W. M. Russell, M. A. Azcarate-Peril, R. Barrangou, B. L. Buck, O. McAuliffe, S. Lick, Proceedings of the National Academy of Sciences, 102, 3906, (2005)

18. H. Toh, K. Oshima, A. Nakano, M. Takahata, M. Murakami, T. Takaki, H. Morita, PloS one, 8, e75073, (2013)

19. M. Kankainen, L. Paulin, S. Tynkkynen, I.von Ossowski, J. Reunanen, P. Partanen, S. C. De Keersmaecker, Proceedings of the National Academy of Sciences, 106, 17193, (2009)

20. J. P.van Pijkeren, C. Canchaya, K. A. Ryan, Y. Li, M. J. Claesson, B. Sheil, P. W. O'Toole, Applied and environmental microbiology, 72, 4143 (2006)

21. E. Call, T. Klaenhammer, Frontiers in microbiology, 4, 73 (2013)

22. B. A. Neville, B. M. Forde, M. J. Claesson, T. Darby, A. Coghlan, K. Nally, P. W. O'Toole, PLoS One, 7, e40592 (2012)

23. M. A. Azcarate-Peril, E. Altermann, Y. J. Goh, R. Tallon, R. B. Sanozky-Dawes, E. A. Pfeiler, M. J. Miller, Applied and environmental microbiology, 74, 4610, (2008)

24. S. Yanagihara, T. Hirota, N.Yamamoto, Journal of bioscience and bioengineering, 114, 582 (2012)

25. N. Ashida, S. Yanagihara, T. Shinoda, N. Yamamoto, Journal of bioscience and bioengineering, 112, 333 (2011)

26. S. R. Konstantinov, H. Smidt, W. M. de Vos, S. C. Bruijns, S. K. Singh, F. Valence, Y.Van Kooyk, Proceedings of the National Academy of Sciences, 105, 19474, (2008)

27. K. Koskenniemi, K. Laakso, J. Koponen, M. Kankainen, D. Greco, P. Auvinen, W. M. de Vos. Molecular \& Cellular Proteomics 10, (2011)

28. J. Koponen, K. Laakso, K. Koskenniemi, M. Kankainen, K. Savijoki, T. A. Nyman, P. Varmanen, Journal of proteomics, 75, 4 (2012)

29. C. Alcantara, M. Zuniga, Microbiology, 158, 1206 (2012)

30. P. A.Bron, C.Grangette, A.Mercenier, W. M.De Vos, \&M.Kleerebezem, Journal of bacteriology, 186, 5721, (2004) 
31. F. J. Troost, P. van Baarlen, P. Lindsey, A. Kodde, W. M. de Vos, M. Kleerebezem, R. J. M. Brummer, BMC genomics, 9, 374 (2008)

32. M. L. Marco, T. H. Peters, R. S. Bongers, D. Molenaar, S. Van Hemert, J. L. Sonnenburg, M. Kleerebezem, Environmental microbiology, 11, 2747 (2009)

33. M. L. Marco, M. C. De Vries, M. Wels, D. Molenaar, P. Mangell, S. Ahrne, M. Kleerebezem, The ISME journal, 4, 1481 (2010)

34. Reverón, B. de las Rivas, R. Muñoz, F. López de Felipe, Molecular nutrition \& food research, 56, 1848 (2012)

35. E. Hamon, P. Horvatovich, E. Izquierdo, F. Bringel, E. Marchioni, D. Aoudé-Werner, S. Ennahar, BMC microbiology, 11, 63 (2011)

36. G. Kozlov, M Pushkarev, E3S Web of Conferences, 135, 01058 (2019) doi:10.1051/e3sconf/201913501058

37. G. Kozlov, M. Pushkarev, V. Mokhna, E3S Web of Conferences, 135, 01052 (2019) doi:10.1051/e3sconf/201913501052

38. K. Lee, K. Pi. Biochemistry (Moscow) 75, 460, (2013)

39. E. Denou, B.Berger, C.Barretto, J. M. Panoff, F. Arigoni, H. Brüssow, Journal of bacteriology, 189, 8109 (2007)

40. J. Sillanpää, B. Martínez, J. Antikainen, T. Toba, N. Kalkkinen, S. Tankka, P. H. Pouwels, Journal of Bacteriology, 182, 6440 (2000)

41. B. L. Buck, E. Altermann, T. Svingerud, T. R. Klaenhammer, Applied and Environmental Microbiology, 71, 8344 (2005)

42. Mandlik, A. Swierczynski, A. Das, H. Ton-That, Trends in microbiology, 16, 33 (2008)

43. D. Granato, G. E. Bergonzelli, R. D. Pridmore, L. Marvin, M. Rouvet, I. E. CorthésyTheulaz, Infection and immunity, 72, 2160 (2004)

44. T. Wall, K. Båth, R. A. Britton, H. Jonsson, J. Versalovic, S. Roos, Applied and environmental microbiology, 73, 3924 (2007)

45. S. Lebeer, T. L. Verhoeven, M. P. Vélez, J. Vanderleyden, S. C. De Keersmaecker, Applied and Environmental Microbiology, 73, 6768 (2007)

46. J. Walter, D. M. Loach, M. Alqumber, C. Rockel, C. Hermann, M. Pfitzenmaier, G. W. Tannock. Environmental microbiology, 9, 1750 (2007)

47. M. H. Sturme, J. Nakayama, D. Molenaar, Y. Murakami, R. Kunugi, T. Fujii, W. M. De Vos, Journal of bacteriology, 187, 5224 (2005)

48. J. Walter, C. Schwab, D. M. Loach, M. G. Gänzle, G. W. Tannock, Microbiology, 154, $72,(2008)$

49. M. C. Joerger, T. R. Klaenhammer, Journal of Bacteriology, 172, 6339 (1990)

50. S. J. Sathe, N. N. Nawani, P. K. Dhakephalkar, B. P. Kapadnis, Journal of Applied Microbiology, 103, 2622 (2007)

51. K. Venema, G. Venema, J. Kok. Trends in microbiology, 3, 299 (1995)

52. K. Hojo, C. Mizoguchi, N. Taketomo, T. Ohshima, K. Gomi, T. Arai, N. Maeda. Bioscience, biotechnology, and biochemistry, 71, 152 (2007)

53. Y. Kawai, J. Kusnadi, R. Kemperman, J. Kok, Y. Ito, M. Endo, T. Saito, Applied and environmental microbiology, 75 (2009)

54. K. Makarova, A. Slesarev, Y. Wolf, A. Sorokin, B. Mirkin, E. Koonin, V. Shakhova, Proceedings of the National Academy of Sciences, 103, 15611 (2006) 
55. P. D. Cotter, C. Hill, R. P. Ross, Nature Reviews Microbiology, 3, 777, (2005)

56. G. L. Lorca, G. F. de Valdez. Calister Academic Press, Norfolk, United Kingdom, 115 (2009)

57. E. A. Pfeiler, M. A. Azcarate-Peril, T. R. Klaenhammer, Journal of bacteriology, 189, 4624 (2007)

58. M. P. Vélez, T. L. Verhoeven, C. Draing, S. Von Aulock, M. Pfitzenmaier, A. Geyer, S. C. De Keersmaecker. Applied and environmental microbiology, 73, 3595 (2007)

59. R. A. Siciliano, G. Cacace, M. F. Mazzeo, L. Morelli, M. Elli, M. Rossi, A. Malorni. Biochimica et Biophysica Acta (BBA)-Proteins and Proteomics, 1784, 335 (2008)

60. F. Cappa, D. Cattivelli, P. S. Cocconcelli. Research in microbiology, 156, 1039 (2005)

61. S. Lebeer, I. J. Claes, T. L. Verhoeven, C. Shen, I. Lambrichts, J. L. Ceuppens, S. C. De Keersmaecker, Applied and Environmental Microbiology, 74, 4711 (2008)

62. M. A. Azcarate-Peril, O. McAuliffe, E. Altermann, S. Lick, W. Russell, T. R. Klaenhammer. Applied and environmental microbiology, 71, 10 (2005)

63. K. Whitehead, J. Versalovic, S. Roos, R. A. Britton. Applied and Environmental Microbiology, 74, 1812 (2008)

64. M. A. Azcarate-Peril, E. Altermann, R. L. Hoover-Fitzula, R. J. Cano, T. R. Klaenhammer, Applied and environmental microbiology, 70, 5315 (2004)

65. T. R. Klaenhammer, R. Barrangou, B. L. Buck, M. A. Azcarate-Peril, E. Altermann. Genomic features of lactic acid bacteria effecting bioprocessing and health. FEMS Microbiology Reviews 29, 393 (2005)

66. T. Duong, R. Barrangou, W. M. Russell, T. R. Klaenhammer. Applied and environmental microbiology, 72, 1218, (2006)

67. R. Barrangou, R. Altermann, Hutkins, R. Cano, T. R. Klaenhammer. Proceedings of the National Academy of Sciences, 100, 8957, (2003)

68. G. R. Gibson, M. B. Roberfroid, The Journal of nutrition, 125, 1401 (1995)

69. M. T. Madigan, D. P. Clark, D. Stahl, J. M. Martinko, Brock biology of microorganisms 13th edition. Benjamin Cummings (2010)

70. L. Axelsson, A. Holck, Journal of Bacteriology, 177, 2125, (1995)

71. L. Axelsson, A. Holck, S. E. Birkeland, T. Aukrust, H. Blom, Applied and environmental microbiology, 59, 2868 (1997)

72. L. Cocolin, K. Rantsiou, Applied microbiology and biotechnology, 76, 1403 (2007)

73. Y. Cui, C. Zhang, Y. Wang, J. Shi, L. Zhang, Z. Ding, H. Cui, International journal of molecular sciences, 13, 16 (2012)

74. K.-H. Lee, H.-J. Lee, H.-C. Chang, D.-K. Chung, J.-H. Lee, J.-H Kim, 390 (2011)

75. M. Skaugen, J. Nissen-Meyer, , G. Jung, S. Stevanovic, K. Sletten, C. Inger, I. F. Nes Journal of Biological Chemistry, 269, 27183 (1994).

76. P. M. Muriana, T. R. Klaenhammer, Journal of bacteriology, 173, 5 (1991)

77. C. Oppegård, G. Fimland, L. Thorbæk, J. Nissen-Meyer. Applied and environmental microbiology, 73, 9 (2007).

78. S. M. Devi, P. M. Halami, Probiotics and antimicrobial proteins, 11, 1 (2019).

79. G. Kasuga, M. Tanaka, Y. Harada, H. Nagashima, T. Yamato, A. Wakimoto, T. Masuda, Applied and environmental microbiology, 85, 6. (2019).

80. Y. Kawai, B. Saitoh, O. Takahashi, H. Kitazawa, T. Saito, H. Nakajima, T. Itoh, Bioscience, biotechnology, and biochemistry, 64, 10 (2000) 
81. C. E. McAlpin, B. Mannarelli, Applied and Environmental Microbiology, 61, 3 (1995)

82. R. J. Leer, J. M. van der Vossen, M.van Giezen, M.Van Noort Johannes, P. H. Pouwels. Microbiology, 141, 7 (1995)

83. Č. Majhenič, K. Venema, G. E. Allison, B. B. Matijašić, I. Rogelj, T. R. Klaenhammer. Applied microbiology and biotechnology, 63, 6 (2004)

84. Fontana, I. Falasconi, P. Molinari, L. Treu, A. Basile, A. Vezzi, L. Morelli, Frontiers in Microbiology, 10 (2019)

85. Maldonado-Barragán, B. Caballero-Guerrero, V. Martín, J. L. Ruiz-Barba, J. M. Rodríguez, BMC microbiology, 16, 1 (2016)

86. S. K Stephens, B.Floriano, D. P. Cathcart, S. A. Bayley, V. F. Witt, R. Jiménez-Díaz, J. L. Ruiz-Barba, Applied and Environmental Microbiology, 64, 5 (1998)

87. K. Surachat, U. Sangket, P. Deachamag, W. Chotigeat. PloS one 12, 8 (2017)

88. G. N., Moll, W. N. Konings, A. J. Driessen. Antonie van Leeuwenhoek, 76 (1999) 